\title{
Material and Dimensional Analysis of Bimetallic Pipe Bend with Defined Bending Radii
}

\author{
Martin SLANY, Josef SEDLAK, Jan ZOUHAR, Oskar ZEMCIK, Josef CHLADIL, Ales JAROS, Karel KOURIL, Matus VARHANIK, \\ Jozef MAJERIK, Igor BARENYI, Robert CEP*
}

\begin{abstract}
This paper deals with material and dimensional bending analysis of bimetallic pipes with defined bending radii. Basic characteristics of selected nickel superalloys with analysis of Inconel 625 and $16 \mathrm{Mo} 3$ steel in terms of primary mechanical properties and chemical composition are presented. In the practical part where the bimetallic tube is analyzed in terms of material properties is also performed geometric dimensional analysis, for which test specimens with different bending radii are made. The capillary test preceded dimensional analysis to remove cracks on the outer bend surfaces of the bimetallic tube. The geometric dimensional analysis itself is carried out using a 3D scanner and also includes external dimensional inspection in longitudinal section with changes in the curvature of bimetallic pipe bends for different bending radii. The article concludes with an overall evaluation of the achieved results, especially with regard to the deviations of rounding in individual sections of the external dimension.
\end{abstract}

Keywords: bimetallic material; dimensional analysis; Inconel 625; material analysis; pipe bend; roundness variations; Steel 16Mo3

\section{INTRODUCTION}

The $1 \mathrm{D}$ elongated pipe bend is at first glance a simple element used in the assembly of complex pipe systems. The contemplated bends are also used for complex serpentine systems. In terms of production, however, the part is relatively complicated with regard to the physical properties of the materials from which it is produced and what requirements are placed on it $[1,2]$.

Direct parts of pipes and bends are offered by many foreign suppliers. The 1D bend is produced as standard today. The material used for the production of tubes is also a major drawback, see Fig. 1. The commonly used material is $16 \mathrm{Mo} 3$ steel, marked according to EN 10027-1. This material degrades rapidly and undergoes rapid destruction in a chemically aggressive environment, particularly in a chlorine-containing environment (incineration plants, but also other plants for the combustion of industrial fuels) and under high operating temperatures $\left(700\right.$ to $\left.1100{ }^{\circ} \mathrm{C}\right)$. The service life of a system fitted with tubular parts of a single material (steel) is approximately half a year in the considered assemblies of plate superheaters, economisers, etc $[1,2]$.

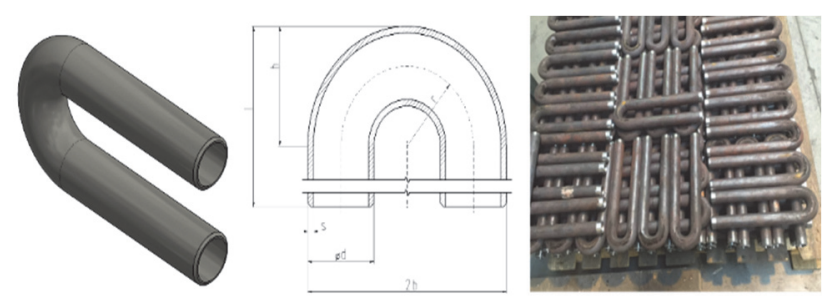

$\emptyset \mathrm{d}$ - external diameter of pipe, $\mathrm{r}$ - bending radius, $\mathrm{b}$ - the bending height, $\mathrm{s}$ - wall thickness, $2 \mathrm{~b}$ - arc width, 1. length of pipe bend $180^{\circ}$ with extended ends

Figure $1 \mathrm{~A}$ pipe bend $180^{\circ}$ formed with the extended end of the one material (normally steel 16Mo3) Bend 1D - normally manufactured part

After material degradation it is necessary to shut down the operation, dismantle the equipment and install new equipment. An alternative to a complete replacement is a complete overhaul, including replacement of worn parts for new ones. At the time of the outage, financial losses occur, eg for heat production, and these operations require significant logistical and technical operations $[1,2]$.

\section{CHARACTERISTIC OF BIMETALLIC MATERIAL}

Currently solved problem consists in production of parts and whole pipe and serpentine systems from bimetallic material, where the basic material is steel tube, which is clad with material Inconel 625 see Fig. 2. The lifetime extension compared to pure steel materials is at least four times, and often the system lifetime is six times longer. Thus, bimetallic materials with a clad layer of Inconel 625 are a suitable alternative for the manufacture of pipe bends and articles thereof $[1,2]$.

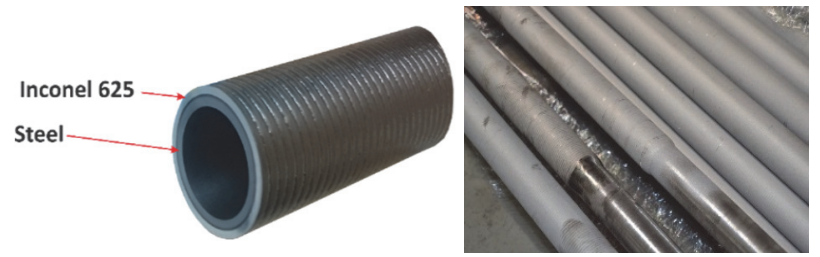

Figure 2 Bimetallic tube ø38mm with clad layer of Inconel 625. Supplier German company UHLIG Rohrbogen $\mathrm{GmbH}$

Forming bimetallic pipes generates a number of critical areas where damage can occur and, as a result, product decommissioning. The critical point is then the outer and inner side of the bend, where different stresses occur. While on the outside of the bend the material is under tension, on the inside of the bend it is under pressure. The smaller the bending radius, the more this force ratio changes significantly. The shortening of the wall on the inside of the bend as compared to the extension on the outside is then $1: 3$ for the $1 \mathrm{D}$ bend. When creating a supercritical bend, i.e. a $0.7 \mathrm{D}$ bend, this ratio changes significantly to 1:6. This has a major influence on the behavior of both materials, particularly in the weld area, where delamination or crack propagation, cracking, as well as the amount of material that is thinned on the outside of the bend and compacted on the inside of the bend, can occur. With this in mind, it is necessary to prepare the workpiece in such a way that there is no significant disparity in the thickness of the weld deposit on the opposite sides $[1,2]$. 


\section{CHARACTERISTICS OF ANALYSED MATERIALS}

The following part will deal with the basic characteristics of selected nickel superalloys. Inconel 625 and $16 \mathrm{Mo} 3$ steel will be characterized in terms of basic mechanical properties and chemical composition.

\subsection{Material Inconel 625}

This material is classified into a group of superalloys, which are characterized as metal alloys. The alloys may be nickel, cobalt or iron-nickel. Nickel alloys account for the largest proportion $[3,4]$.

\subsubsection{Characteristics of Nickel Superalloys}

Nickel superalloys are used in the most demanding conditions, especially at high temperatures ranging from 900 to $1100{ }^{\circ} \mathrm{C}$, as well as in an acidic and chemically aggressive environment such as municipal waste incineration and industrial fuels. These materials are resistant to oxidation, corrosion and fatigue life. In industry, they are then used in aviation for engine production, oil and gas extraction or shipyards and nuclear power plants. The chemical composition of selected superalloys is given in Tab. 1 [3-6].

Table 1 Composition of selected superalloys of Inconel materials [5]

\begin{tabular}{|c|c|c|c|c|c|c|c|c|c|c|}
\hline $\begin{array}{c}\text { Composition } \\
\text { Wt. } \%\end{array}$ & $\mathrm{Cr}$ & $\mathrm{Ni}$ & $\mathrm{Co}$ & $\mathrm{Mo}$ & $\mathrm{Cu}$ & $\mathrm{Nb}$ & $\mathrm{Ti}$ & $\mathrm{Al}$ & $\mathrm{Fe}$ & $\mathrm{C}$ \\
\hline Inconel 600 & 15.50 & 76.00 & - & - & 0.25 & 25.00 & - & - & 8.00 & 0.08 \\
\hline Inconel 601 & 23.00 & 60.50 & - & - & - & - & - & 1.35 & 14.10 & 0.05 \\
\hline Inconel 617 & 22.00 & 55.00 & 12.50 & 9.00 & - & - & - & 1.00 & 0.07 & - \\
\hline Inconel 625 & 21.50 & 61.00 & - & 9.00 & - & 3.60 & 0.20 & 0.20 & 2.50 & 0.05 \\
\hline Inconel 718 & 19.00 & 52.50 & - & 3.00 & 0.15 & 5.10 & 0.90 & 0.50 & 18.50 & 0.08 \\
\hline $\begin{array}{c}\text { Inconel } \\
\mathrm{X}-750\end{array}$ & 15.50 & 73.00 & - & - & 0.25 & 1.00 & 2.50 & 0.70 & 7.00 & 0.04 \\
\hline
\end{tabular}

\subsubsection{Microstructure of Nickel Superalloys}

Similar to austenitic steels, these superalloys have an austenitic matrix. The microstructure and macrostructure can be seen in Fig. 3 and Fig. 4.

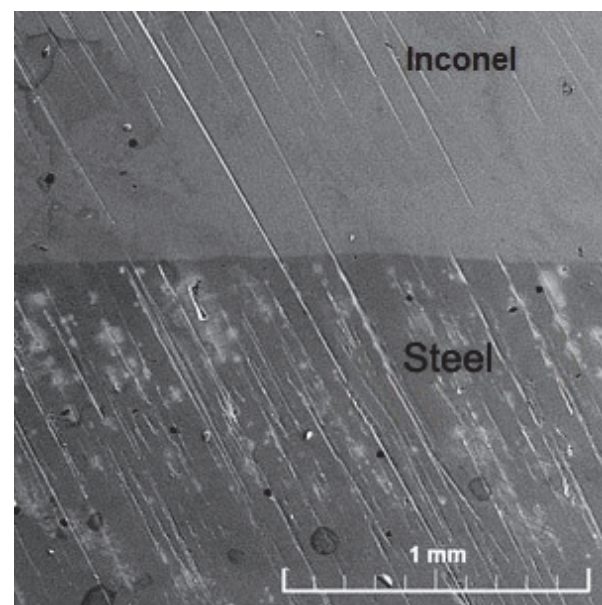

Figure 3 Macrostructure of $16 \mathrm{Mo} 3$ steel and Inconel 625

The structures consist of two-phase equilibrium microstructure: $\gamma$ basic phase - solid solution of nickel strengthened by substitutional alloying elements (FCC) and the intermetallic $\gamma$ phase $\mathrm{Ni} 3 \mathrm{Nb}$ precipitates, which is in the main curing (FCC). In some types of Inconel (706, 718 ), the main curing phase becomes the $\gamma$ phase with a tetragonal spatially centered lattice (BCC) because the alloy has a higher niobium content $(\mathrm{Nb})[3,5]$.

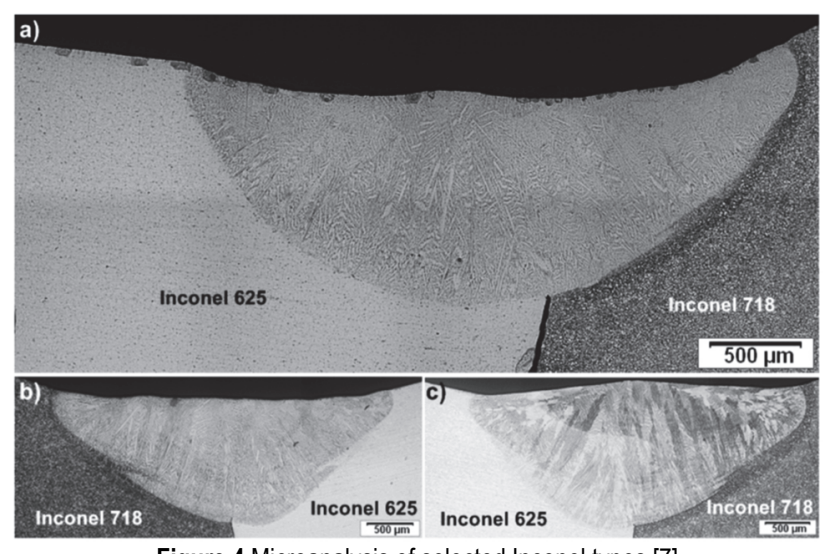

Figure 4 Microanalysis of selected Inconel types [7]

\subsubsection{Mechanical Properties of Material Inconel 625}

In terms of machining-influencing properties, nickel alloys are classified into groups A through E. The analyzed Inconel 625 belongs to group D as a material curable by the aging process. It is in this state that high strength and hardness are maintained. Annealing followed by quenching is performed as a chemical-heat treatment of this alloy to obtain better machinability in the aging roughing process. In drilling and threading operations, it is necessary to have low hardness of the material, and so it is machined in an aged state. The basic mechanical properties of Inconel 625 are shown in Tab. 2. Tab. 3 shows the mechanical properties of selected Inconel materials at selected temperatures $[3,4]$.

Table 2 Basic mechanical properties of Inconel 625 [6]

\begin{tabular}{|c|c|}
\hline Density & $8.44 \mathrm{gcm}^{-3}$ \\
\hline Ductility at $20{ }^{\circ} \mathrm{C}$ & $50 \%$ \\
\hline Tensile modulus at $20{ }^{\circ} \mathrm{C}$ & $207 \mathrm{GPa}$ \\
\hline Hardness before cold forming & $200 \mathrm{HV}$ \\
\hline Creep strength & $360 \mathrm{MPa}$ \\
\hline
\end{tabular}

Table 3 Mechanical properties of selected Inconel materials at selected temperatures [5]

\begin{tabular}{|c|c|c|c|c|c|c|}
\hline \multirow{2}{*}{ Material } & \multicolumn{3}{|c|}{ Tensile strength / MPa } & \multicolumn{3}{c|}{ Yield strength / MPa } \\
\cline { 2 - 7 } & $21{ }^{\circ} \mathrm{C}$ & $540^{\circ} \mathrm{C}$ & $760{ }^{\circ} \mathrm{C}$ & $21^{\circ} \mathrm{C}$ & $540^{\circ} \mathrm{C}$ & $760^{\circ} \mathrm{C}$ \\
\hline Inconel 600 & 660 & 560 & 260 & 285 & 220 & 180 \\
\hline Inconel 601 & 740 & 725 & 290 & 455 & 350 & 220 \\
\hline Inconel 617 & 740 & 580 & 440 & 295 & 200 & 180 \\
\hline Inconel 625 & 965 & 910 & 550 & 490 & 415 & 415 \\
\hline Inconel 718 & 1435 & 1275 & 950 & 1185 & 1065 & 740 \\
\hline $\begin{array}{c}\text { Inconel } \\
\text { X-750 }\end{array}$ & 1200 & 1050 & - & 815 & 725 & - \\
\hline
\end{tabular}

\subsection{Material Steel 16Mo3}

16Mo3 grade steel designated according to ČSN 15 020 standard belongs to low-alloy steels with increased resistance to high temperatures, high-temperature corrosion and creep. Due to its higher Mo and $\mathrm{Cr}$ content, 
$16 \mathrm{Mo} 3$ steel is used primarily in the heating, power, oil, gas or chemical industries. At present, however, this material is mainly used in the production of industrial boilers, steam lines, heat exchangers or pressure vessels. The indisputable advantage of this material is its very good weldability using conventional welding methods (TIG, MAG). Chemical composition of $16 \mathrm{Mo} 3$ steel is shown in Tab. 4 and mechanical properties in Tab. 5. Tab. 6 shows the creep rupture strengths after a load time of 105 hours at several different temperatures [8-11].

Table 4 Chemical composition of steel 16Mo3 [10]
\begin{tabular}{|c|c|c|c|c|c|c|c|c|c|c|}
\hline $\begin{array}{c}\text { Comp. } \\
\text { Wt. / } \%\end{array}$ & $\mathrm{C}$ & $\mathrm{Si}$ & $\mathrm{Mn}$ & $\mathrm{P}$ & $\mathrm{S}$ & $\mathrm{Cr}$ & $\mathrm{Mo}$ & $\mathrm{Ni}$ & $\mathrm{N}$ & $\mathrm{Cu}$ \\
\hline $16 \mathrm{Mo3}$ & $\begin{array}{c}0.12 \\
\text { to } \\
0.20\end{array}$ & 0.35 & $\begin{array}{c}0.40 \\
\text { to } \\
0.90\end{array}$ & 0.025 & 0.01 & 0.03 & $\begin{array}{c}0.25 \\
\text { to } \\
0.35\end{array}$ & 0.30 & 0.012 & 0.30 \\
\hline
\end{tabular}

Table 5 Mechanical properties of steel 16Mo3 [10]

\begin{tabular}{|c|c|}
\hline Tensile modulus & $212 \mathrm{GPa}$ \\
\hline Yield strength & $380 \mathrm{MPa}$ \\
\hline Sterngth limit & $440 \mathrm{MPa}$ \\
\hline Hardness & $150 \mathrm{HB}$ \\
\hline Ductility & $30 \%$ \\
\hline ISO-V impact work & $31 \mathrm{~kJ}$ \\
\hline Application temperatures & -20 to $530^{\circ} \mathrm{C}$ \\
\hline
\end{tabular}

Table 6 Creep rupture strengths after 105 hours load at several different temperatures [10]

\begin{tabular}{|c|c|}
\hline Temperature $/{ }^{\circ} \mathrm{C}$ & Creep rupture strength $/ \mathrm{MPa}$ \\
\hline 450 & 293 \\
\hline 470 & 178 \\
\hline 500 & 101 \\
\hline 510 & 91 \\
\hline 530 & 53 \\
\hline
\end{tabular}

Fig. 5 shows the ferritic-pearlitic structure of $16 \mathrm{Mo} 3$ steel.

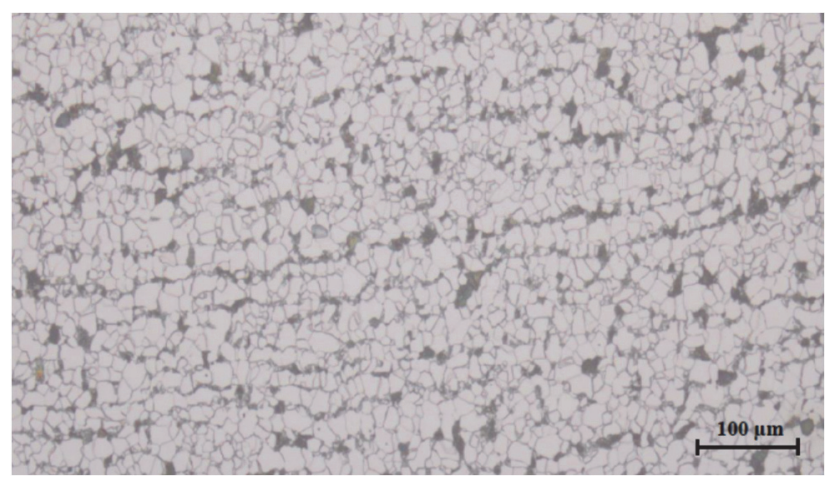

Figure 5 Ferritic-pearlitic structure of steel $16 \mathrm{Mo} 3$

\section{EXPERIMENTAL PART - MATERIAL ANALYSIS}

The subject of the analysis was a bimetallic tube with elongated ends with $1 D$ bend, which was tested for material analyses, especially analysis of chemical composition, material structure, microhardness and presence of cracks.

\subsection{Macroanalysis of Bimetallic Pipe Bend}

Fig. 6 shows a composite cross-sectional view of the inner bend of a pipe bend where it is seen that the pipe walls change during your bend. The pipe tight walls are used in the range from 10 to $13 \mathrm{~mm}$. Tight welds are used in the range from 3.7 to $6.9 \mathrm{~mm}$ [12-20].

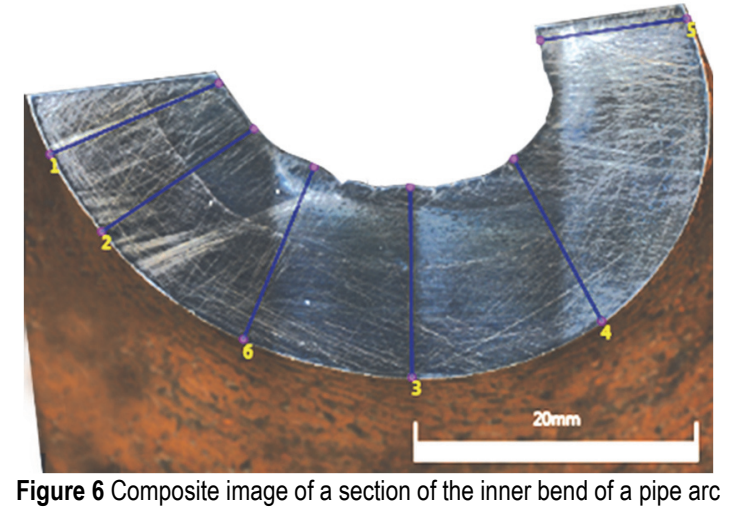

The external wall thickness of the bend of the tubular arc, see Fig. 7, is in the range of 7.5 to $8.6 \mathrm{~mm}$. The thickness of the weld deposit is between 2.8 and $3.2 \mathrm{~mm}$.

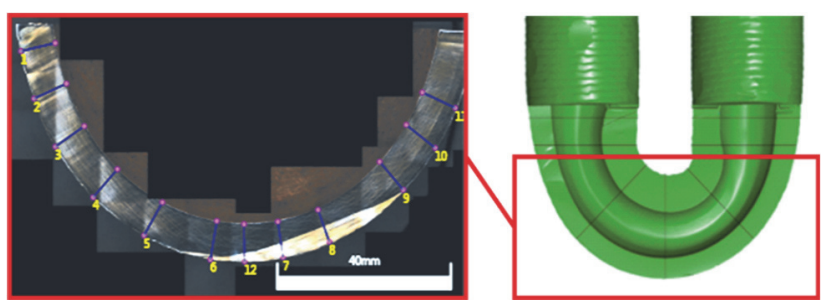

Figure 7 Measurement of pipe bend outer wall thickness

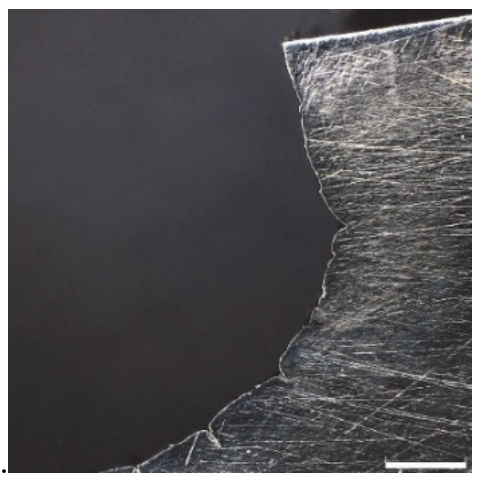

Figure 8 Detail of the inner bend of the pipe arc without cracks

Fig. 8 shows a detail of the inner bend of the tubular arc where no cracks are visible in the section.

In Fig. 9 you can see the non-etched material Inconel, under which the heat-affected region of the steel is shown, where the martensitic structure and small sorbitan regions can be observed [12-16].

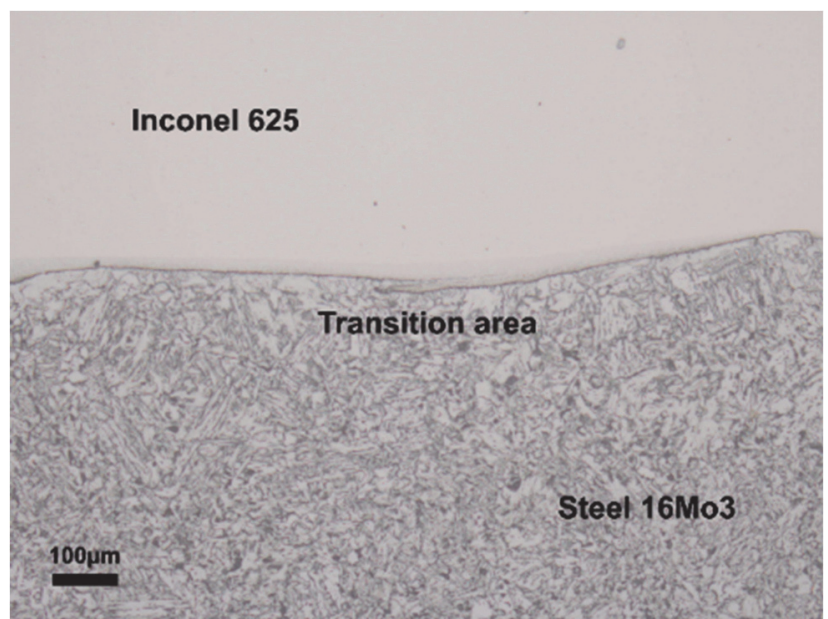

Figure 9 Microstructure of bimetallic pipe - straight part 


\subsection{Microhardness of Bimetallic Pipe Arc}

Microhardness measurements were performed using a Vickers indentor at a load of $0.5 \mathrm{~kg}$ and a load time of 13 s. Fig. 10 shows a cross-section hardness map. The microhardness of Inconel was $250 \mathrm{HV} 0.5$ for the transition area and approximately $200 \mathrm{HV} 0.5$ for the base area and $170 \mathrm{HV} 0.5$ for the base material [12-16].

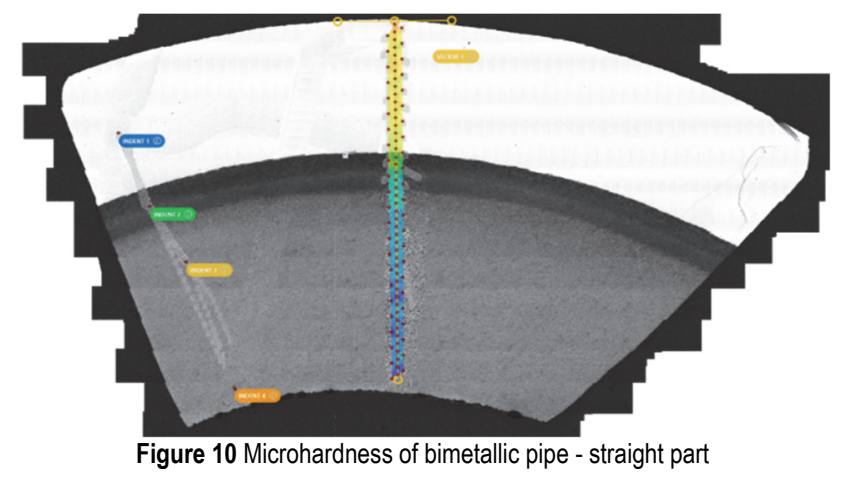

\subsection{Microanalysis of Chemical Composition of Bimetallic Pipe Arc}

The cut segment of a pipe bend has been documented from the outer surface in the cylindrical part see Fig. 11 by a Tescan Vega TS 5135 electron microscope.

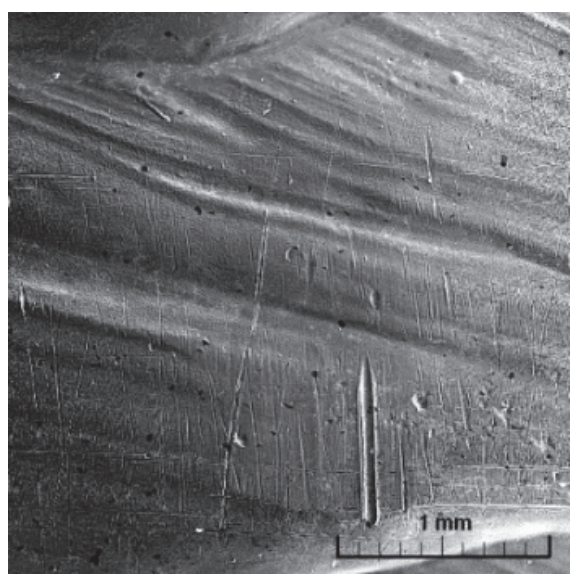

Figure 11 Material Inconel 625 - outer surface

Furthermore, an interface between the Inconel 625 outer tube and the $16 \mathrm{Mo} 3$ inner steel tube was seen in cross-section, see Fig. 12.

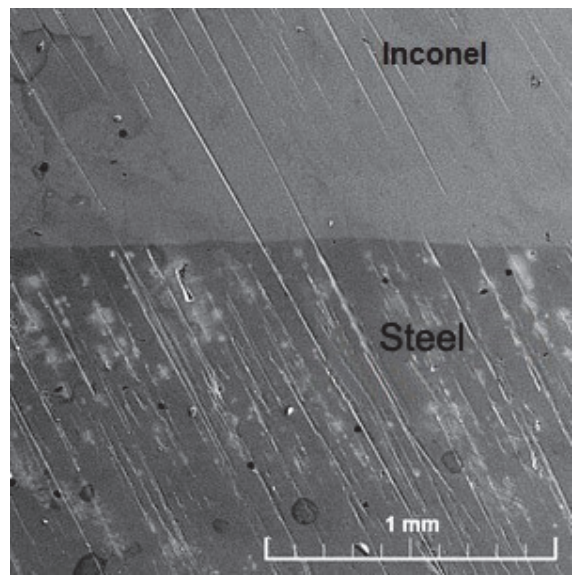

Figure 12 Interface between outer and inner pipe
Microanalysis of chemical composition of both materials was performed by EDS method using Noran Six/300.

\subsection{Analysis of Inconel 625 Material from Bimetallic Pipe Bend Surface}

The analysis of the chemical composition was carried out first from the surface on the material Inconel 625. The analyzed area with the measurement direction is shown in Fig. 13. The microanalysis itself took place in two steps, where in the first step, see Fig. 14, mainly the basic elements of Inconel 625, i.e. $\mathrm{Ni}$ and $\mathrm{Cr}$, were analyzed and in the second step, see Fig. 15, less represented elements were analyzed because of the frequency of points collected on the $y$-axis $[12-16,21,22]$.

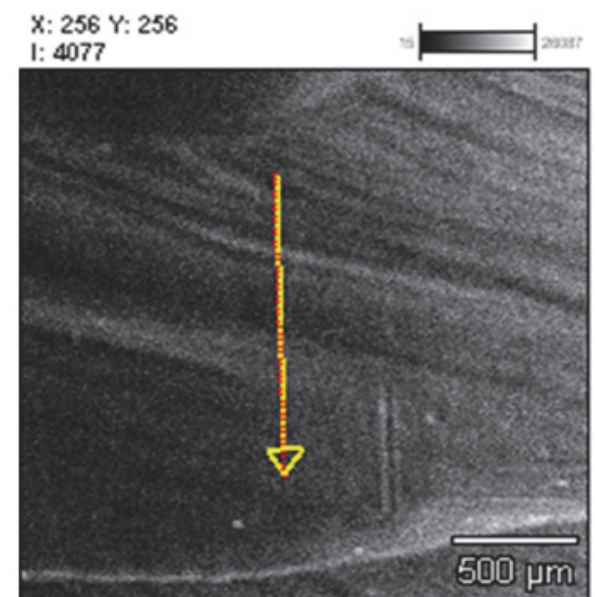

Figure 13 Surface analyzed - Inconel 625 material

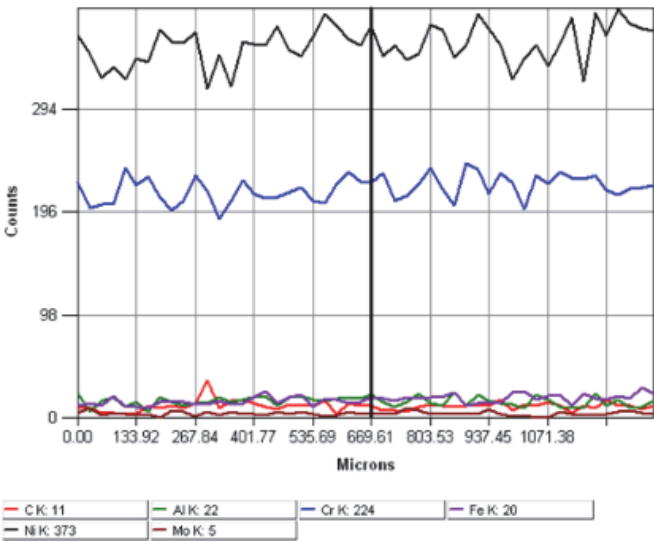

Figure 14 Microanalysis of Inconel 625 surface - main elements

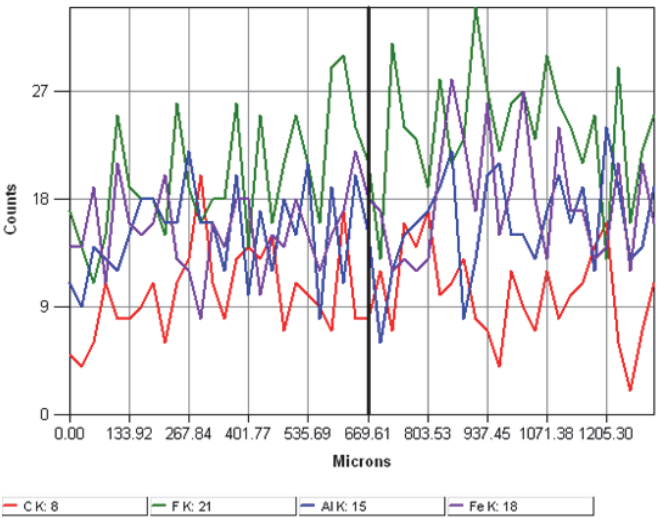

Figure 15 Microanalysis of Inconel 625 surface - accompanying elements 
Tab. 7 shows the percentage of individual analyzed elements from the surface of Inconel 625 in weight and atomic percentages. The values obtained are given with relative measurement error.

Table 7 Chemical composition of Inconel 625 in weight and atomic percentages

\begin{tabular}{|c|c|c|c|c|}
\hline Element & $\begin{array}{c}\text { Wt. } \\
/ \%\end{array}$ & Wt. Error / \% & $\begin{array}{c}\text { Atom. } \\
/ \%\end{array}$ & Atom. Error / \% \\
\hline $\mathrm{C}$ & 5.61 & $+/-4.70$ & 20.36 & $+/-20.36$ \\
\hline $\mathrm{F}$ & 4.18 & $+/-4.18$ & 9.58 & $+/-13.17$ \\
\hline $\mathrm{Al}$ & 0.87 & $+/-0.79$ & 1.40 & $+/-1.40$ \\
\hline $\mathrm{Cr}$ & 24.35 & $+/-1.78$ & 20.40 & $+/-1.48$ \\
\hline $\mathrm{Fe}$ & 0.63 & $+/-0.63$ & 0.49 & $+/-0.69$ \\
\hline $\mathrm{Ni}$ & 64.37 & $+/-5.26$ & 47.77 & $+/-3.87$ \\
\hline
\end{tabular}

\subsection{Interface Analysis of Inconel 625 Material and 16Mo3 Steel in a Cross-Section of Bimetallic Pipe Bend}

Fig. 16 shows the interface between the two materials and the measuring outward direction, i.e., from the Inconel 625 material inward through the $16 \mathrm{Mo} 3$ steel inner pipe interface.

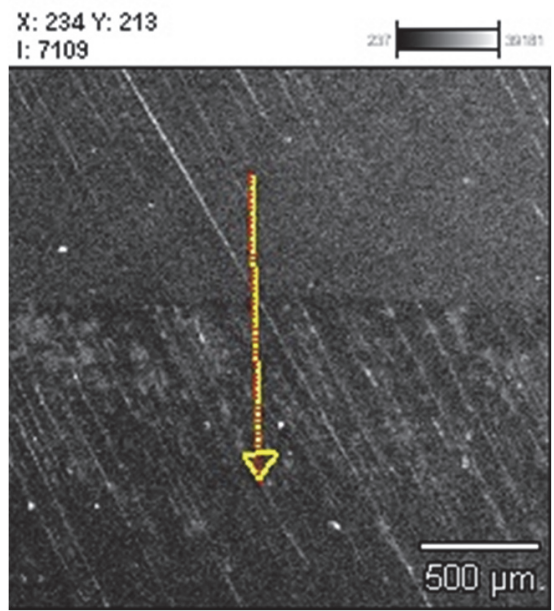

Figure 16 Interface of Inconel 625 - steel $16 \mathrm{Mo3}$

Fig. 17 shows the interface of the base materials when measuring the chemical composition in line. At the moment of a significant decrease in $\mathrm{Ni}$ (brown) and $\mathrm{Cr}$ (blue) from Inconel 625 material, there is a significant increase in Fe (black) in the inner 16Mo3 steel pipe. The increase in $\mathrm{F}$ (red) is also interesting.

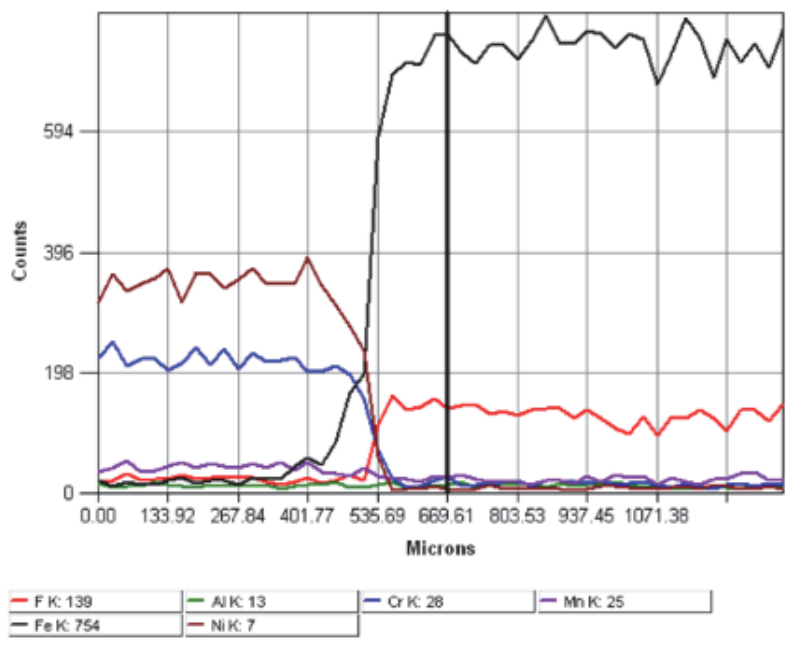

Figure 17 The course of elements layout on the interface of Inconel 625 - steel $16 \mathrm{Mo3}$
Fig. 18 shows the points where the chemical composition was measured. Above the interface, point 2, the chemical composition is made in Inconel 625 material, see tab. 8 , where the spectrum of interest elements is shown in Fig. 19. Below the interface, point No. 3, the measurement is made in $16 \mathrm{Mo} 3$ steel inner pipe material. Chemical composition is shown in Tab. 9, where the spectrum of interest elements is shown in Fig. 20.

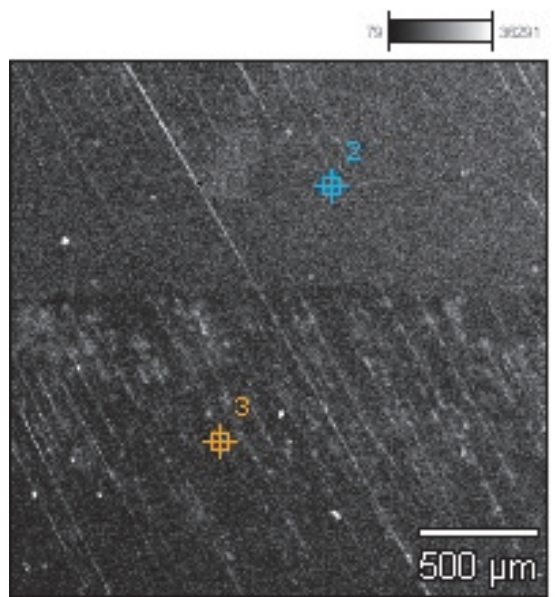

Figure 18 Positions of chemical composition measurements: point 2 - Inconel 625 material; point 3 - $16 \mathrm{Mo} 3$ steel material

Table 8 Chemical composition of Inconel 625 material, point 2

\begin{tabular}{|c|c|c|c|c|}
\hline Element & $\begin{array}{c}\text { Wt. } \\
/ \%\end{array}$ & $\begin{array}{c}\text { Wt. Error } \\
/ \%\end{array}$ & $\begin{array}{c}\text { Atom. } \\
/ \%\end{array}$ & $\begin{array}{c}\text { Atom. Error } \\
/ \%\end{array}$ \\
\hline $\mathrm{Cr}$ & 23.70 & $+/-0.45$ & 27.13 & $+/-0.52$ \\
\hline $\mathrm{Ni}$ & 64.71 & $+/-1.02$ & 65.60 & $+/-1.03$ \\
\hline $\mathrm{Nb}$ & 3.82 & $+/-0.60$ & 2.45 & $+/-0.39$ \\
\hline $\mathrm{Mo}$ & 7.77 & $+/-0.45$ & 4.82 & $+/-0.28$ \\
\hline
\end{tabular}

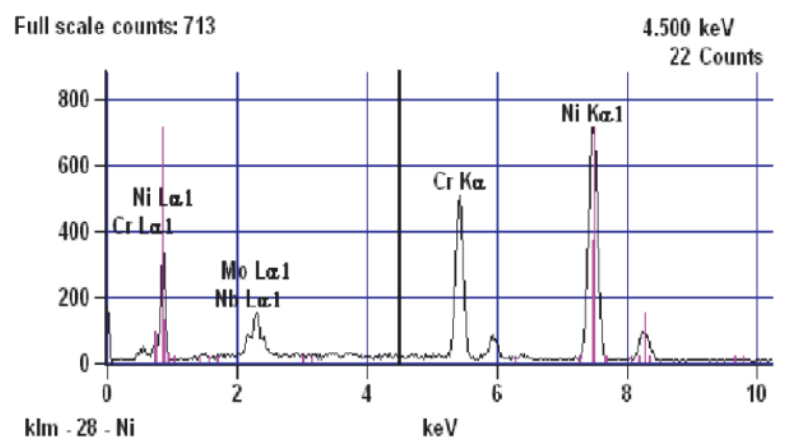

Figure 19 Spectrum of interest - point 2 in Fig. 18

Table 9 Chemical composition of $16 \mathrm{Mo} 3$ steel material, point 3

\begin{tabular}{|c|c|c|c|c|}
\hline Element & $\begin{array}{c}\mathrm{Wt} . \\
/ \%\end{array}$ & $\begin{array}{c}\text { Wt. Error } \\
/ \%\end{array}$ & $\begin{array}{c}\text { Atom. } \\
/ \%\end{array}$ & $\begin{array}{c}\text { Atom. Error } \\
/ \%\end{array}$ \\
\hline $\mathrm{Mn}$ & 0.87 & $+/-0.16$ & 0.89 & $+/-0.17$ \\
\hline $\mathrm{Fe}$ & 99.13 & $+/-0.96$ & 99.11 & $+/-0.96$ \\
\hline
\end{tabular}

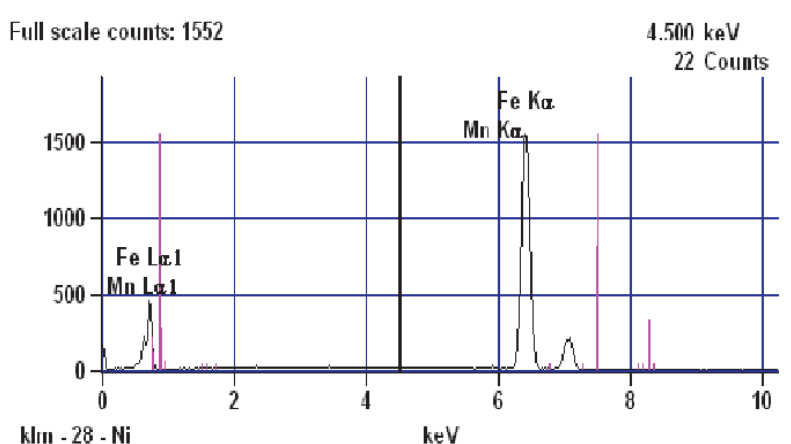

klin - 28 - N

Figure 20 Spectrum of interest - point 3 in Fig. 18 


\section{EXPERIMENTAL PART - GEOMETRIC ANALYSIS OF BENDS}

Dimensional bending analysis was performed on the basis of requirements and observance of given dimensions. For this purpose, bend samples were made for $1 D$ and $0.7 D$ radius, see Fig. 21. The capillary testing was carried out on the samples to eliminate cracks on external surfaces according to ČSN EN ISO 3452-1, see Fig. 22. These samples were subsequently $3 \mathrm{D}$ scanned by the device GOM Atos Compact Scan 2M, MV 250. The MR 2000 antireflective chalk spray was applied for scanning purposes [17, 18]. According to the requirements, the external dimension in longitudinal section was checked and the deviation of roundness of the pipe bends (inspection according to CSN EN 12952-5), in spite of the fact that this standard does not affect materials with welded metal deposit Inconel, it was used for inspection.

The roundness deviation of the pipe bends is calculated from the equation:

$u=2 \frac{\hat{d}_{\mathrm{o}}-\breve{d}_{\mathrm{o}}}{\hat{d}_{\mathrm{o}}+\breve{d}_{\mathrm{o}}} \times 100$

where: $u / \%$ roundness deviation, $\hat{d}_{\mathrm{o}} / \mathrm{mm}$ maximum outside diameter measured at the top of the tubular profile, $\breve{d}_{\mathrm{o}} / \mathrm{mm}$ is the minimum outside diameter measured in the same cross section as $\hat{d}_{\mathrm{o}}$.

The limit value for roundness deviation is $1 D$ for the bending radius, $u=12 \%$. For a bending radius of $0.7 D$, it is not specified by the standard for one continuous operation. Using the value determined for bending in two operations and heat treatment, the value of $u=18 \%$.

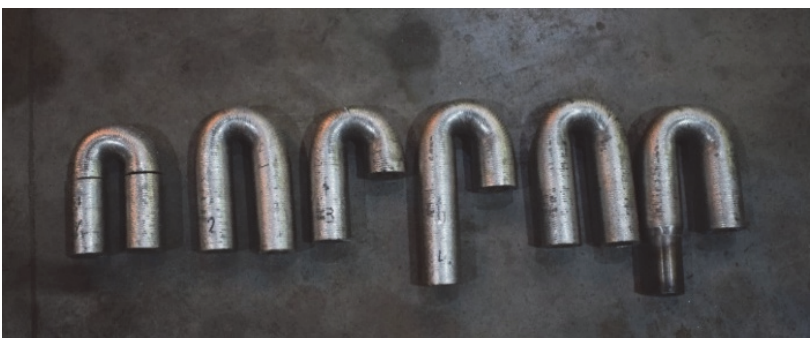

Figure $21 \mathrm{~A}$ part of tubular samples for geometric analysis of defined bending radius of $0.7 D$

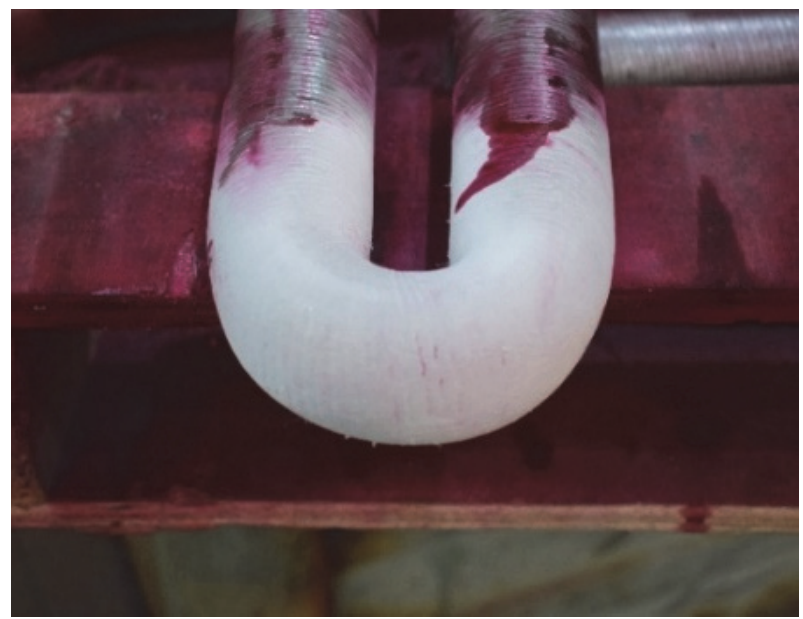

Figure 22 A capillary test

\subsection{Defined Bending Radius 1D}

The course of deviations from the theoretical CAD model in relation to the measured sample is evident from Fig. 23, the area of stamping and drawing of material on the inner and outer radius is significant. There was unevenness in the area of the inner rushing area, which is given by the shape of the tool used and the course of the bending by gradual rolling on the tool at a constant speed $[17,18]$.

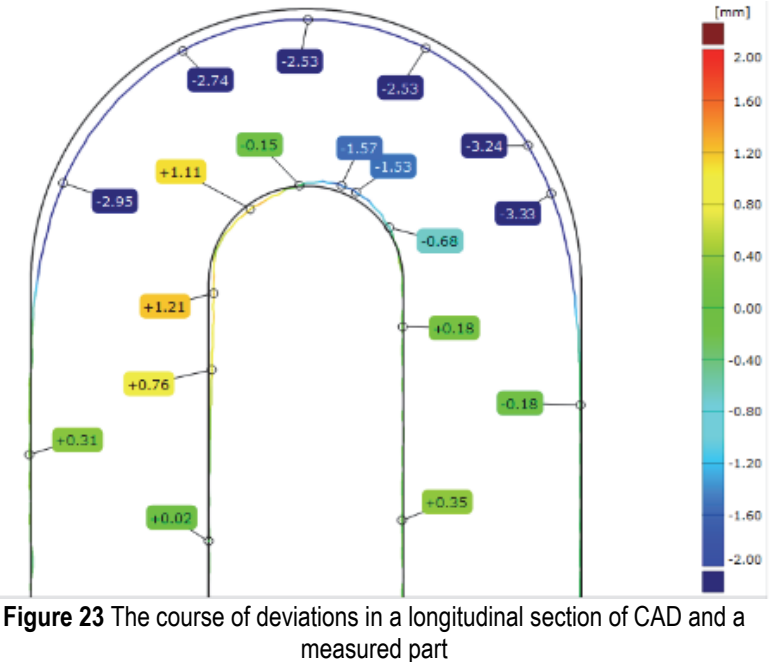

The deviations of roundness of the shape are evaluated in sections of $45^{\circ}$, see Fig. 24. The evaluation of individual sections is in Tab. 10 .

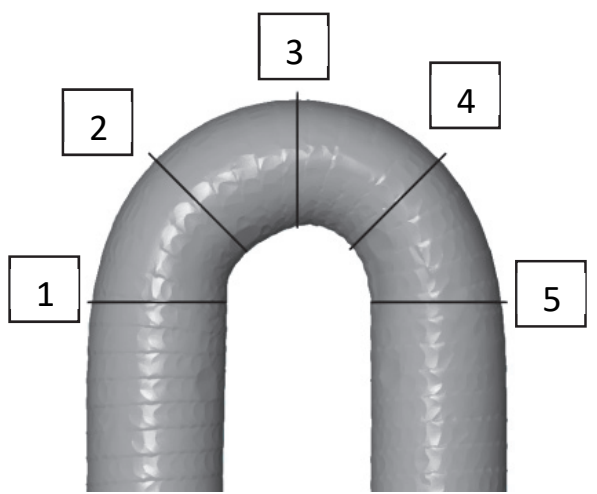

Figure $24 \mathrm{~A}$ position of a section at defined bending radius $1 D$

Table 10 Deviation of sample roundness on defined bending radius $1 D$

\begin{tabular}{|c|c|c|c|}
\hline Cut No. & $\hat{d}_{\mathrm{o}} / \mathrm{mm}$ & $\breve{d}_{\mathrm{o}} / \mathrm{mm}$ & $u / \%$ \\
\hline 1 & 43 & 41.7 & 3.06 \\
\hline 2 & 43.23 & 40.27 & 7.08 \\
\hline 3 & 44.35 & 38.89 & 13.11 \\
\hline 4 & 44.28 & 38.11 & 14.97 \\
\hline 5 & 43.27 & 40.4 & 6.86 \\
\hline
\end{tabular}

At the points of the sections 3 and 4, the circularity value is exceeded, a non-uniform deformation not corresponding to the shape of the tool can be observed on the longitudinal section. This is caused due to the stamping of the material and its pushing away from the tool. The method of filling the pipes with loose or fusible material is used to improve the bending geometry of the pipe. However, this method is rather suitable for thin-walled pipes. In this case, both the Inconel weld and the $16 \mathrm{Mo} 3$ 
steel material cracked during the forming of the filled pipes. An alternative to obtain better geometric bending properties of a bimetallic thick-walled pipe is to use a compensated tool that will be applied in the next phase of the research.

\subsection{Defined Bending Radius of 0.7D}

Four samples formed under constant conditions were evaluated for the $0.7 \mathrm{D}$ bend. The only variable parameter was the bending speed. The evaluation is shown in Fig. 25. The samples 2 and 4 were molded at the same bending rate, the sample 6 at a reduced bending rate of $25 \%$. A smaller deformation can be observed on the external tensile surface in the sample 6. Forming conditions, tool shape and dimensions and machine setting parameters are the subject for further research and development $[17,18]$.

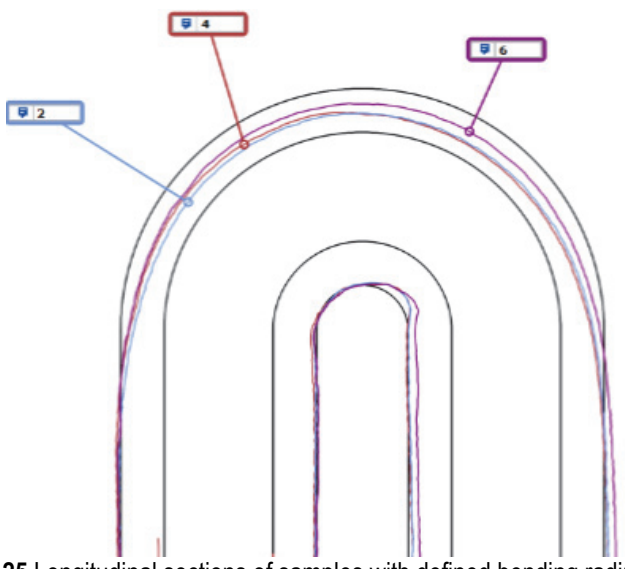

Figure 25 Longitudinal sections of samples with defined bending radius of $0.7 D$

The sample No. 1 from the first series was cut by cutting to evaluate the internal surfaces and geometry, see the composite scanned model in Fig. 26.

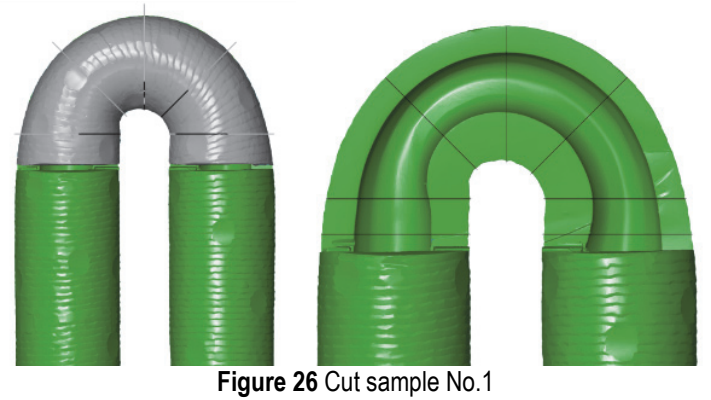

In the model in Fig. 26, it is evident also the section planes used to evaluate the dimensions of the circularity deviation for the external dimension (see Tab. 11) and also for inner pipe dimension, see Fig. 27 and Tab. 12.

Table 11 Circular deviation of the outer diameter sample at a defined bending radius of $0.7 D$

\begin{tabular}{|c|c|c|c|}
\hline Cut No. & $\hat{d}_{\mathrm{o}} / \mathrm{mm}$ & $\breve{d}_{\mathrm{o}} / \mathrm{mm}$ & $u / \%$ \\
\hline 1 & 43.78 & 43.03 & 1.72 \\
\hline 2 & 42.71 & 41.75 & 2.27 \\
\hline 3 & 42.26 & 37.32 & 12.41 \\
\hline 4 & 42.54 & 39.55 & 7.28 \\
\hline 5 & 42.72 & 39.49 & 7.85 \\
\hline 6 & 43.57 & 41.23 & 5.51 \\
\hline 7 & 44.66 & 43.45 & 2.74 \\
\hline
\end{tabular}

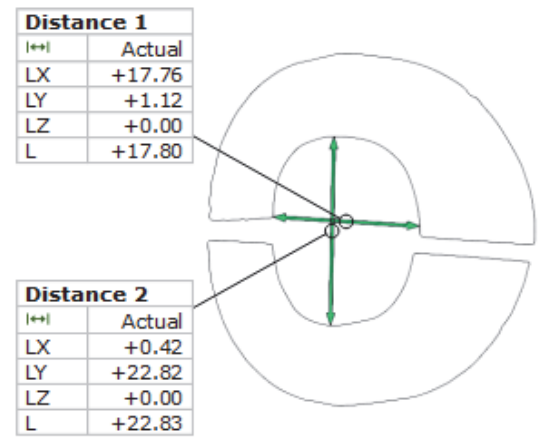

Figure 27 A section with evaluated dimensions

Table 12 Evaluation of roundness deviation of the inner tubular dimension

\begin{tabular}{|c|c|c|c|}
\hline Cut No. & $\hat{d}_{\mathrm{o}} / \mathrm{mm}$ & $\breve{d}_{\mathrm{o}} / \mathrm{mm}$ & $u / \%$ \\
\hline 1 & 25.34 & 24.56 & 3.12 \\
\hline 2 & 24.19 & 22.08 & 9.12 \\
\hline 3 & 23.19 & 16.91 & 31.32 \\
\hline 4 & 22.82 & 17.76 & 24.93 \\
\hline 5 & 23.31 & 18.45 & 23.27 \\
\hline 6 & 24.51 & 19.91 & 20.71 \\
\hline 7 & 25.37 & 22.58 & 11.63 \\
\hline
\end{tabular}

The roundness deviation for the external dimension corresponds to the standard values. The internal dimension is not defined by the shape standard and is only subject to a ball test that has been passed successfully. The circularity values were evaluated for comparison with the parts manufactured on a compensated tool and under modified conditions.

\section{CONCLUSIONS}

The article deals with material and dimensional analysis of bimetallic pipe arc with defined bending radii of $1 D$ and $0.7 D$. Material analysis of bimetallic pipe arc with defined bending radius $1 D$ was focused on macroanalysis of bending, microhardness, microanalysis of chemical composition, analysis of Inconel 625 material from the surface and interface analysis of Inconel 625 and $16 \mathrm{Mo} 3$ steel in a cross section.

Geometric dimensional analysis was performed on experimentally produced bimetallic pipe test samples with defined critical and supercritical bends of $1 D$ and $0.7 D$ radii. A part of this analysis was checking the external dimension in a longitudinal section and deviations of roundness. The measurement and evaluation that have been carried out, in particular with regard to the circularity deviations in the individual sections for the external dimension, show that the resulting circularity deviations correspond to the standard values. The inner dimension is not defined by the shape standard and is only subjected to a ball test, which was successful too. The circularity values were evaluated for subsequent comparison with parts made on a compensated tool and under modified forming conditions.

The precondition for the production of these formed bimetallic parts is to obtain knowledge of forming a tubular arc with a defined bending radius, which is the most complex in the system under consideration $\left(180^{\circ}\right.$ arc with $0.7 D$ bend). By welding the formed serpentine systems into assemblies, then sub-assemblies of superheater, plate superheater, economizer, etc. systems can be formed into 
the combustion chambers commonly used in the power industry.

Systems with considered bimetallic pipes can be effectively used even in an environment with a high concentration of aggressive chemical elements, such as chlorine arising from the incineration of municipal waste in incinerators. In such environment, the use of bimetallic tubular components can extend the system life to more than four times.

\section{Acknowledgements}

This research was supported by project No. FV40173 as part of the fourth public tender in the TRIO program of the Ministry of Industry and Trade and also was supported by the Slovak Research and Development Agency under the contract No. APVV-15-0710.

\section{REFERENCES}

[1] Golański, G., Lachowicz, M., Słania, J., Jasak, J., \& Marszałek, P. (2015). Research on 16Mo3 (16M) Steel Pipes Overlaid with Haynes Nicro625 Alloy Using MIG (131) Method. Archives of Metallurgy and Materials, 60(4), 25212524. https://doi.org/10.1515/amm-2015-0408

[2] Rozmus-Górnikowska, M., Blicharski, M., Kusiński, J., Kusiński, L., \& Marszycki, M. (2013). Influence of boiler pipes cladding methods on their microstructure and properties. Archives of Metallurgy and Materials, 58(4), 1093-1096. https://doi.org/10.2478/amm-2013-0131

[3] Píška, M., et al. (2009). Special technology of machining. CERM, Brno, $1^{\text {st Edition, } 246 .}$

[4] INCONEL ${ }^{\circledR}$ Alloy 625. Special Metals. Retrieved from https://www.specialmetals.com/assets/smc/documents/alloy s/inconel/inconelalloy25.pdf?fbclid=IwAR2bGkR0Nn6sswj oyPX4EfnstEykkL7zL7Cn8cQ-ci_iCI0wtph5yYnizHw

[5] Petrvaldský, T. (2018). Tapering ofthe Inconel 600 alloy by rotary forging method. Ostrava. Bachelor Thesis. VSB TU Ostrava. Supervisor: Martin Kraus, PhD, MSc.

[6] Nickel Alloys. Bibus Metals. Retrieved from http://new.bibus.cz/pdf/Special_Metals/Nikl/Niklove_slitin y.pdf

[7] Strelczak, K. \& Dudek, A. (2018). The structure and coefficient of friction of welded nickel alloys inconel 625 and inconel 718. Tribologia, 2018(5), 109-115. https://doi.org/10.5604/01.3001.0012.7660

[8] 16Mo3 Chrome Moly Steel. AZoM.com. Masteel UK, C 2000-2019, 29.5.2010. Retrieved from https://www.azom.com/article.aspx?ArticleID $=5244$

[9] New steel from Ostrava will be used mainly in power engineering. Tech. Magazín. Prague: TECH MEDIA PUBLISHING s r.o., (C) 2010-2019, 13.5.2015. Retrieved from http://www.techmagazin.cz/2138

[10] Material No.: 1.5415. M. Woite Sonderwerkstoffe Edelstähle. Erkrath: M. Woite, 2012. Retrieved from http://www.woite-edelstahl.com/15415en.html\#

[11] Steel grades. Metalmax, s.r.o. Frýdek-Místek: Metalmax, s.r.o, 2005. Retrieved from http://www.metalmax.cz/znacky.php

[12] Belan, J., Jambor, M., Kuchař́ková, L., TIillova, E., Chalupová, M., \& Matvija, M. (2017). The SEM investigation of inconel 718 fatigue process at various loading conditions. Manufacturing Technology, 17(5), 658665 . https://doi.org/10.21062/ujep/x.2017/a/1213-2489/MT/17/5/658

[13] Belan, J., Hurtralova, L., Vasko, A., \& Tillova, E. (2014). Metallography evaluation of IN 718 after applied heat treatment. Manufacturing Technology, 14(3), 262-267.
https://doi.org/10.21062/ujep/x.2014/a/1213-2489/MT/14/3/262

[14] Dobrocký, D., Dostál, P., Šustr, M., Pokorný, Z., \& Studený, Z. (2018). Analysis of weld joint of DX51D steel with AlMg3 alloy made by CMT welding method. Manufacturing Technology, 18(2), 215-221. https://doi.org/10.21062/ujep/80.2018/a/1213-2489/MT/18/2/215

[15] Barényi, I., Majerík, J., Pokorný, Z., Sedlák, J., Bezecný, J., Dobrocký, D., Jaroš, A., Eckert, M., Jambor, J., \& Kusenda, R. (2019). Material and technological investigation of machined surfaces of the OCHN3MFA steel. Kovové Materiály - Metallic Materials, 57(2), 131-142. https://doi.org/10.4149/km_2019_1_131

[16] Pokorný, Z., Dobrocký, D., Kaldlec, J., \& Studený, Z. (2018). Influence of alloying elements on gas nitriding process of high-stressed machine parts of weapons. Kovové Materiály - Metallic Materials, 56(2), 97-103. https://doi.org/10.4149/km_2018_2_97

[17] Sedlák, J., Polzer, A., Chladil, J., Slaný, M., \& Jaroš, A. (2017). Shape Inspection of Gear Prototypes Using Reverse Engineering Method. Manufacturing Technology, 17(6), 945-952. https://doi.org/10.21062/ujep/x.2017/a/1213-2489/MT/17/6/945

[18] Sedlák, J., Polzer, A., Chladil, J., Slaný, M., \& Jaroš, A. (2017). Reverse Engineering Method Used for Inspection of Stirrer's Gearbox Cabinet Prototype. MM Science Journal, 17(4), 1877-1882. https://doi.org/10.17973/MMSJ.2017_11_201719

[19] Ayer, Ö. (2017). A numerical study for prediction of forming load and experimental verification of bimettalic disc opsetting. Tehnički Vjesnik - Technical Gazette, 24(6), 1679-1688 https://doi.org/10.17559/TV-20160130154750

[20] Kiss, J. \& Maksay, S. (2010). Bimettalic cast iron rolls some approaches to assure the exploitation properties. Tehnički Vjesnik - Technical Gazette, 17(2), 173-178.

[21] Petrů, J., Zlamal, T., Čep, R., Monkova, K., \& Monka, P. (2013). Influence of cutting parameters on heat affected zone after laser cutting.Tehnički Vjesnik - Technical Gazette, 20(2), 225-230.

[22] Barényi, I., Majerík, J., Bezecný, J., Krba'a, M., Sedlák, J., \& Jaroš, A. (2019). Material and technological aspects while processing of seleceted ultra high strength steel. Manufacturing Technology, 19(2), 184-189. https://doi.org/10.21062/ujep/267.2019/a/1213-2489/MT/19/2/184

\section{Contact information:}

Martin SLANÝ, PhD, MSc

Brno University of Technology, Faculty of Mechanical Engineering, Institute of Manufacturing Technology,

Technická 2896/2, 61669 Brno, Czech Republic

E-mail: slany.m@fme.vutbr.cz

Josef SEDLÁK, Assoc. Prof., PhD, MSc.

Brno University of Technology, Faculty of Mechanical Engineering, Institute of Manufacturing Technology,

Technická 2896/2, 61669 Brno, Czech Republic

E-mail: sedlak@fme.vutbr.cz

Jan ZOUHAR, PhD, MSc.

Brno University of Technology, Faculty of Mechanical Engineering, Institute of Manufacturing Technology,

Technická 2896/2, 61669 Brno, Czech Republic

E-mail: zouhar@fme.vutbr.cz

Oskar ZEMČíK, PhD, MSc.

Brno University of Technology, Faculty of Mechanical Engineering,

Institute of Manufacturing Technology,

Technická 2896/2, 61669 Brno, Czech Republic

E-mail: zemcik.o@fme.vutbr.cz 
Josef CHLADIL, Assoc. Prof., PhD, MSc.

Brno University of Technology, Faculty of Mechanical Engineering,

Institute of Manufacturing Technology,

Technická 2896/2, 61669 Brno, Czech Republic

E-mail: chladil@fme.vutbr.cz

Aleš JAROŠ, PhD, MSc.

Brno University of Technology, Faculty of Mechanical Engineering, Institute of Manufacturing Technology,

Technická 2896/2, 61669 Brno, Czech Republic

E-mail: jaros.a@fme.vutbr.cz

Karel KOUŘIL, Assoc. Prof., PhD, MSc.

Brno University of Technology, Faculty of Mechanical Engineering,

Institute of Manufacturing Technology,

Technická 2896/2, 61669 Brno, Czech Republic

E-mail: Karel.Kouril@vutbr.cz

\section{Matúš VARHANÍK, MSc.}

Brno University of Technology, Faculty of Mechanical Engineering,

Institute of Manufacturing Technology

Technická 2896/2, 61669 Brno, Czech Republic

E-mail: Matus.Varhanik@vutbr.cz

Jozef MAJERÍK, Assoc. Prof., PhD, MSc.

Alexander Dubcek University of Trencin, Faculty of special technology,

Department of Engineering,

Pri Parku 19, 91106 Trenčín, Slovak Republic

E-mail: jozef.majerik@tnuni.sk

Igor BARÉNYI, Assoc. Prof., PhD, MSc.

Alexander Dubcek University of Trencin, Faculty of special technology,

Department of Engineering,

Pri Parku 19, 91106 Trenčín, Slovak Republic

E-mail: igor.barenyi@tnuni.sk

Robert ČEP, Prof., PhD, Msc.

(Corresponding author)

VŠB-Technical University of Ostrava

Faculty of Mechanical Engineering

Department of Machining, Assembly and Engineering Metrology,

17. listopadu 15, 708 33, Ostrava, Czech Republic

E-mail: robert.cep@vsb.cz 